\title{
PENINGKATAN MOTIVASI BELAJAR MAHASISWA TERHADAP PRESTASI BELAJAR ALJABAR MATRIKS
}

\author{
Nita Hidayati \\ Pendidikan Matematika Universitas Singaperbangsa Karawang \\ Email: nita.hidayati@fkip.unsika.ac.id
}

\begin{abstract}
The objectives of this research is examine the impact of learning motivation of students in algebra matrix. Data collection techniques used in this study is the observation, questionnaires, tests, and documentation. The population in this study is a second semester student of Mathematics Education in UNSIKA Karawang. This research used purposive sampling techniques that have one class into the sample. In this study the researchers used one shot case study design. It is the result of observation after treatment. Indicators and variables that measured is learning achievement that includes the value of the midterm as the independent variable and final exams as the dependent variable. Data analysis is using Wilcoxon signed rank test. In the Wilcoxon signed rank test $\left(T_{h}=22.5, n=20, T_{h}=22.5<47=T_{k}\right)$ showed that the learning motivation significantly increasing the value of UTS and UAS. The value of $T^{+}=187.5>22.5=T^{-}$Means there is an increased motivation to learn students from UTS to UAS. This shows that the impact is positive motivation to learn. Therefore, the motivation has positive benefits for increase the value of UTS and UAS college students.
\end{abstract}

Keywords: algebra matrix, learning motivation, students

\section{PENDAHULUAN}

Di perguruan tinggi Universitas Negeri Singaperbangsa Karawang jurusan Pendidikan Matematika, aljabar matriks dikaji sebagai mata kuliah wajib yang harus diikuti. Adapun nilai hasil belajar aljabar matriks dari dua tahun terakhir tergolong rendah, sehingga perlu adanya upaya dari dosen aljabar matriks agar prestasi belajar mahasiswa tergolong baik.

Dalam belajar aljabar matriks menghafal rumus bukanlah suatu cara yang tepat, tetapi dibutuhkan suatu pemahaman baik dari simbol, rumus, konsep, definisi dan ketelitian analisisnya. Selain itu, terdapat motivasi belajar yang berfungsi sebagai pendorong usaha dalam pencapaian prestasi.
James O. Whittaker (Soemanto, 2006) mengemukakan belajar adalah suatu proses yang dilakukan individu untuk memperoleh suatu perubahan tingkah laku yang baru secara keseluruhan, sebagai hasil pengalaman individu itu sendiri dalam interaksi dengan lingkungannya. Teori belajar yang disusun Gagne (Aunurrahman, 2009) merupakan perpaduan yang seimbang antara Behaviorisme dan kognitivisme yang berpangkal pada teori pengolahan informasi. Menurut Gagne cara berpikir seseorang tergantung pada keterampilan apa yang telah dimilikinya dan keterampilan serta hirarki apa yang diperlukan untuk mempelajari suatu tugas. Dengan demikian menurut Gagne di dalam proses belajar terdapat dua fenomena, yaitu meningkatnya keterampilan 
intelektual sejalan dengan meningkatnya umur serta latihan yang diperoleh individu, dan belajar akan lebih cepat bilamana strategi kognitif dapat dipakai dalam memecahkan masalah secara lebih efisien. Lerner (Abdurrahman, 1999) mengemukakan bahwa kurikulum bidang studi matematika hendaknya mencakup tiga elemen, yaitu konsep, keterampilan dan pemecahan masalah.

Menurut Sardiman (2006: 73), motivasi dapat dikatakan sebagai serangkaian usaha untuk menyediakan kondisi-kondisi tertentu, sehingga seseorang itu mau dan ingin melakukan sesuatu, dan bila ia tidak suka, maka akan berusaha untuk meniadakan perasaan tidak suka itu. Uno (2007: 27) menyatakan bahwa beberapa peranan penting dari motivasi dalam belajar dan pembelajaran adalah (a) Menentukan hal-hal yang dapat dijadikan penguat belajar; (b) Memperjelas tujuan belajar yang hendak dicapai; (c) Menentukan ragam kendali terhadap rangsangan belajar; dan (d) Menentukan ketekunan belajar. Menurut Sardiman (2006: 84), intensitas motivasi seorang peserta didik akan sangat menentukan tingkat pencapaian prestasi belajarnya. Indikator motivasi belajar adalah perhatian (attention), relevansi (relevance), percaya diri (confidence) dan kepuasan (satisfaction). Menurut Suciati, sebagaimana dikutip oleh Yosua (2012: 5), perhatian adalah bentuk pengarahan untuk dapat berkonsultasi/pemusatan pikiran dalam menghadapi peserta didik dalam peristiwa proses belajar mengajar di kelas.

Tujuan dalam penelitian ini untuk mengkaji dampak motivasi terhadap prestasi belajar mahasiswa dalam mata kuliah aljabar matriks.

\section{METODE PENELITIAN}

Penelitian ini merupakan penelitian kualitatif interaktif case study. Dalam penelitian ini metode yang digunakan adalah metode deskriptif, yaitu penelitian yang berusaha untuk mendeskripsikan suatu gejala peristiwa atau kejadian secara sistematis dan akurat mengenai sifat-sifat populasi. Pengambilan sampel dalam penelitian ini menggunakan teknik purposive sampling. Dengan cara undian maka dari 6 kelas diambil satu kelas untuk menjadi sampel. Indikator dan variabel yang diukur meliputi Nilai Ujian Akhir Semester (UAS) sebagai variabel terikat dan nilai Ujian Tengah Semester (UTS) sebagai variabel bebas. Setelah data diperoleh dari hasil soal UTS dan UAS, kemudian dilakukan analisis data yakni uji peringkat bertanda wilcoxon.

\section{HASIL PENELITIAN DAN PEMBAHASAN}

Dalam penelitian ini, untuk mengetahui peningkatan prestasi belajar, penulis memutuskan untuk membandingkan hasil UTS dan UAS. Laporan hasil UTS dan UAS dinyatakan dalam tabel berikut. 
ISSN 2089-8703 (Print) Vol. 6, No. 1 (2017)

ISSN 2442-5419 (Online)

Tabel 1. Laporan Nilai Mahasiswa

\begin{tabular}{|c|c|c|c|c|c|}
\hline Kode & Nilai UTS & Nilai UAS & Kode & Nilai UTS & Nilai UAS \\
\hline 01 & 80 & 97 & 11 & 73 & 97 \\
\hline 02 & 77 & 97 & 12 & 94 & 100 \\
\hline 03 & 72 & 100 & 13 & 76 & 30 \\
\hline 04 & 94 & 90 & 14 & 62 & 100 \\
\hline 05 & 36 & 100 & 15 & 80 & 97 \\
\hline 06 & 72 & 97 & 16 & 83 & 100 \\
\hline 07 & 55 & 70 & 17 & 79 & 100 \\
\hline 08 & 50 & 60 & 18 & 88 & 98 \\
\hline 09 & 72 & 97 & 19 & 88 & 82 \\
\hline 10 & 75 & 97 & 20 & 63 & 98 \\
\hline
\end{tabular}

Karena ukuran sampel kecil, prosedur non parametrik lebih baik dibandingkan uji parametrik. Oleh sebab itu, penguji menerapkan uji peringkat bertanda Wilcoxon.

Tahap-tahap pengujian yang dilaksanakan adalah sebagai berikut:

1. Menyatakan hipotesis null dan hipotesis riset

Gagasan dari penulis adalah jika nilai UTS tinggi maka nilai UAS juga akan tinggi. Atas dasar gagasan itu, penulis merumuskan hipotesis berikut:

Hipotesis null $H_{0}: m_{d}=0$, dan hipotesis riset $H_{1}: m_{d}>0$
2. Menetapkan taraf risiko

Penulis memilih taraf risiko $\alpha=0.05$, artinya dia memilih taraf kepercayaan $95 \%$ untuk mengamati adanya peningkatan persentase.

3. Memilih statistik uji yang cocok Karena hanya ada 20 mahasiswa $(n=20)$, maka menggunakan uji peringkat bertanda Wilcoxon.

4. Menghitung statistik uji Ini meliputi beberapa tahap:

4.1 Menghitung perbedaan setiap data yang berpasangan

4.2 Membuat peringkat pada perbedaan dengan mengabaikan tanda dan perbedaan 0 . Hasil dari langkah ini disajikan dalam Tabel 2. 
ISSN 2089-8703 (Print) Vol. 6, No. 1 (2017)

ISSN 2442-5419 (Online)

Tabel 2. Laporan Data Nilai dalam Uji Peringkat Bertanda Wilcoxon

\begin{tabular}{|c|c|c|c|c|c|}
\hline Kode & Nilai UTS & Nilai UAS & Selisih & Peringkat & Tanda \\
\hline 01 & 80 & 97 & 17 & 8 & + \\
\hline 02 & 77 & 97 & 20 & 10 & + \\
\hline 03 & 72 & 100 & 28 & 16 & + \\
\hline 04 & 94 & 90 & -4 & 1 & - \\
\hline 05 & 36 & 100 & 64 & 20 & + \\
\hline 06 & 72 & 97 & 25 & 14.5 & + \\
\hline 07 & 55 & 70 & 15 & 6 & + \\
\hline 08 & 50 & 60 & 10 & 4.5 & + \\
\hline 09 & 72 & 97 & 25 & 14.5 & + \\
\hline 10 & 75 & 97 & 22 & 12 & + \\
\hline 11 & 73 & 97 & 24 & 13 & + \\
\hline 12 & 94 & 100 & 6 & 2.5 & + \\
\hline 13 & 76 & 30 & -46 & 19 & - \\
\hline 14 & 62 & 100 & 38 & 18 & + \\
\hline 15 & 80 & 97 & 17 & 8 & + \\
\hline 16 & 83 & 100 & 17 & 8 & + \\
\hline 17 & 79 & 100 & 21 & 11 & + \\
\hline 18 & 88 & 98 & 10 & 4.5 & + \\
\hline 19 & 88 & 82 & -6 & 2.5 & - \\
\hline 20 & 63 & 98 & 35 & 17 & + \\
\hline & & & & & \\
\hline
\end{tabular}

4.3 Menghitung jumlah peringkat yang perbedaannya posistif $\left(\mathrm{T}^{+}\right)$

dan jumlah peringkat yang perbedaannya negatif $\left(T^{-}\right)$dari

Tabel 2.

Dari tabel ini diperoleh

$T^{+}=187.5$ dan $T^{-}=22.5$.

4.4 Menghitung

$$
\begin{aligned}
& T_{h}=\min \left(T^{+}, T^{-}\right)= \\
& \min (187.5,22.5)=22.5
\end{aligned}
$$

\section{Menentukan $\boldsymbol{T}_{k}$}

Karena $n=20$. Untuk $\alpha=0.05$ maka diperoleh nilai kritik $T_{k}=47$.

6. Membuat keputusan

Karena $T_{h}=22.5<47=T_{k}$ maka hipotesis null ditolak.

\section{Mengartikan hasil}

Karena $T_{h}=22.5<47=T_{k}$ maka penulis menyatakan "ada cukup bukti bahwa jika nilai UTS tinggi maka nilai UAS juga akan tinggi”. Nilai $\quad T^{+}=187.5>22.5=T^{-}$ menunjukkan bahwa nilai UAS meningkat, artinya terdapat peningkatan motivasi belajar mahasiswa dari UTS sampai UAS.

Bila membahas hasil, maka temuan harus dijelaskan. Temuan ini meliputi (1) statistik $T_{h}$, (2) ukuran sampel, (3) nilai- $p$ yang dikaitkan dengan $\alpha$ (untuk $n>30$ ) atau pembandingan $T_{h}$ dan $T_{k}$, dan (4) arah perbedaan (pembandingan $T^{+}$ dan $T^{-}$).

Dalam uji peringkat bertanda Wilcoxon $\quad\left(T_{h}=22.5\right.$, 


$$
\begin{aligned}
& \mathrm{n}=20, T_{h}=22.5<47=T_{k} \text { ) } \\
& \text { menunjukkan bahwa motivasi } \\
& \text { belajar signifikan dalam } \\
& \text { peningkatan nilai UTS dan nilai } \\
& \text { UAS. } \\
& T^{+}=187.5>22.5=T^{-} \\
& \text {memperlihatkan bahwa dampak } \\
& \text { motivasi belajar adalah positif. Oleh } \\
& \text { sebab itu, motivasi belajar } \\
& \text { mempunyai manfaat posistif untuk } \\
& \text { peningkatan nilai UTS dan nilai } \\
& \text { UAS mahasiswa. }
\end{aligned}
$$

\section{KESIMPULAN DAN SARAN}

Berdasarkan hasil analisis dan pembahasan pada keseluruhan tahapan penelitian, diperoleh kesimpulan bahwa motivasi belajar mempunyai manfaat posistif untuk peningkatan nilai UTS dan nilai UAS mahasiswa.

Berdasarkan kesimpulan yang diperoleh, adapun saran dalam penelitian ini adalah pada proses pembelajaran sangat diperlukan motivasi, sehingga untuk meningkatkan hasil belajar mahasiswa maka diperlukan peningkatan motivasi belajar mahasiswa.

\section{DAFTAR PUSTAKA}

Abdurrahman, M. 1999. Pendidikan Bagi Anak Berkesulitan Belajar. Jakarta. Rineka Cipta

Aunurrahman. 2009. Belajar dan Pembelajaran. Bandung: Alfabeta.

Sardiman. 2006. Interaksi dan Motivasi Belajar Mengajar. Jakarta: Raja Grafindo Persada.

Soemanto, W. 2006. Psikologi Pendidikan Landasan Kerja Pemimpin Pendidikan: Jakarta. Rineka Cipta.

Uno, H.B. 2007. Teori Motivasi dan Pengukurannya. Jakarta: Bumi Aksara.

Yosua, A.W. 2012. Pengaruh Perhatian, Relevansi, Kepercayaan Diri, dan
Kepuasan Terhadap Motivasi

Belajar Mahasiswa Fakultas

Ekonomi Jurusan Manajemen

Universitas Riau di Pekanbaru. Pekan Baru: Universitas Riau. 